\title{
Cloning, Expression, and Characterization of Thermostable DNA Polymerase from Thermoanaerobacter yonseiensis
}

\author{
Dae Jin Kim, Hyeung Jin Jang, Yu Ryang Pyun and Yu Sam Kim ${ }^{\dagger} *$ \\ Programs in Biomaterials Science and Engineering, \\ Department of Biochemistry, College of Science, Yonsei University, Seoul 120-749, Korea
}

Received 28 January 2002, Accepted 6 March 2002

\begin{abstract}
A gene, coined tay, for a thermostable DNA polymerase from the novel, extremely thermophilic bacterium Thermoanaerobacter yonseiensis was cloned and expressed in $E$. coli. Using a DNA polymerase homologous PCR product as a hybridization probe, tay was isolated and sequenced to consist of $\mathbf{2 6 1 6}$ nucleotides that encode 872 amino acids. A database analysis showed that DNA polymerase, coined Tay, from T. yonseiensis shared a 39\% to $47 \%$ identity in the amino acid sequence with those from other DNA polymerases. Tay was overexpressed in $E$. coli as a fusion protein with a poly-histidine tag at the $\mathbf{C}$ terminus. It was purified by heat treatment, followed by a $\mathrm{Ni}^{2+}$-chelate column. The molecular weight of purified Tay was approximately $97 \mathrm{kDa}$, as shown by SDS PAGE, and it showed high DNA polymerase activity and thermostability. However, it had no 3' $\rightarrow$ ' ' exonuclease activity.
\end{abstract}

Keywords: Thermoanaerobacter yonseiensis, Thermostable DNA polymerase.

\section{Introduction}

DNA polymerases are key enzymes in the replication of cellular information that is present in all living things. They are a family of enzymes that are involved in DNA replication and repair.

Beginning with the isolation and characterization of DNA polymerase I from Escherichia coli by Kornberg and colleagues in the 1950s (Kornberg, 1980), more than 50 DNA polymerases have been cloned and sequenced from various organisms, including thermopile and archaea. DNA polymerases have been used extensively in molecular biology. For example, DNA polymerase I was used for the nicktranslation of DNA and synthesis of the second strand of

*To whom correspondence should be addressed.

Tel: 82-2-2123-2699; Fax: 82-2-392-3488

E-mail; yskim@yonsei.ac.kr
cDNA in cDNA cloning (Efstratiadis et al., 1976). The modified version of bacteriophage T7 DNA polymerase (Sequenase $^{\mathrm{TM}}$ ) was used for the dideoxy sequencing of DNA (Tabor and Richardson, 1987). Thermostable DNA polymerase, such as Taq DNA polymerase, has been the key element in the development of the polymerase chain reaction (PCR) (Saiki et al., 1988; Mullis et al., 1986). PCR was also performed using the Klenow fragment of E.coli DNA polymerase I. However, it needs to be added every cycle after the denaturation and primer hybridization steps since this enzyme is heat-sensitive. The application of thermostable DNA polymerase in PCR makes the automation of PCR possible. Taq DNA polymerase from Thermus aquaticus was the first characterized thermostable enzyme (Chien, 1976). Thereafter, many DNA polymerases from the Thermus strain were studied. Tfl, Tth, Tfi, and Top polymerase have been applied to PCR (Kaledin et al, 1981; Ruttimann et al, 1985; Jung et al., 1997; Kim et al., 1998); however, their baseinsertion fidelity is low because these DNA polymerases do not have 3 ' $\rightarrow 5$ ' exonuclease activity. The high-fidelity of DNA polymerases, which has $3^{\prime} \rightarrow 5$ ' exonuclease-dependent proofreading activity, should be required for error correction during the polymerization. Several thermostable DNA polymerases with proofreading activity (Pfu, Vent, deep Vent, and $P w o$ ) have also been studied and introduced for highfidelity PCR amplification (Cariello et al., 1991; Lunberg et al., 1991; Kong et al., 1993; Frey and Suppmann, 1995; Cline et al., 1996).

Most of the native thermostable enzymes are synthesized at very low levels by the thermophilic bacteria; therefore, they are cumbersome to purify. So thermostable DNA polymerase, such as $P f u$ DNA polymerase, was produced in a biologically active form in the E.coli over-expression system ( $\mathrm{Lu}$ and Erickson, 1997; Dabrowski and Kur, 1998). However, several problems persist, such as error-prone amplification and unwanted amplification at low temperatures in the PCR applications. New and improved thermostable DNA polymerases are needed. 
In this report, we describe the discovery of a gene that encodes a novel DNA polymerase from thermoanaerobic bacteria, Thermoanaerobacter yonseiensis KB-1 (Kim et al., 2001). This organism is known as one of the most heatresistant bacteria. Enzymes from this bacteria showed a higher heat-stability (Jang et al., 2002). The thermostable DNA polymerase (Tay) from the cloned gene was over-expressed in E. coli and characterized.

\section{Materials and Methods}

Preparation of the $T$. yonseiensis $K B-1$ genomic DNA library T. yonseiensis genomic DNA was partially digested with Sau3AI. The fragments (lengths, 2-12 kb) were ligated into the ZAP EXPRESS vector/BamHI (Stratagene, N. Torrey Pines Road, La Jolla, USA). They were packaged using a Gigapack III Gold packaging extract (Stratagene, La Jolla, USA).

Preparation of the homologous primer and PCR From an amino acid sequence alignment of known bacterial DNA polymerases, a highly conserved sequence was selected in order to make a probe. Degenerate primers were designed, based on the conserved sequence. The sense primer was 5' CC(AGCT)-AA(CT)(CT)T(AGCT)-CA(AG)-AA(CT)-AT(ATC)-CC(AGCT) 3'. The antisense primer was 5', (AGCT)A(AG)-(CT)TC-(AG)TC-(AGCT) $\mathrm{A}(\mathrm{CT})-(\mathrm{CT}) \mathrm{TG}$ 3'. A polymerase chain reaction (PCR) was performed in a total volume of $50 \mu \mathrm{l}$ using the PCR system 2400 (Applied Biosystems, Foster City, USA). The mixture contained 0.5 unit of Taq DNA polymerase, $5 \mu \mathrm{l}$ of $10 \times \mathrm{Taq}$ DNA polymerase buffer, $0.2 \mathrm{mM}$ of each dNTP, 100 pmole of each primer, and $0.5 \mu \mathrm{g}$ of T. yonseiensis genomic DNA. PCR was performed by 30 amplification cycles on the condition, denaturation $\left(96^{\circ} \mathrm{C}, 2 \mathrm{~min}\right)$, annealing $\left(46 \sim 51^{\circ} \mathrm{C}, 1 \mathrm{~min}\right)$, and extension $\left(72^{\circ} \mathrm{C}, 30 \mathrm{~s}\right)$. After the final cycle, the reaction mixture was kept at $72^{\circ} \mathrm{C}$ for $7 \mathrm{~min}$.

DNA probe preparation The PCR product was detected with ethidium bromide staining on $1 \%$ agarose gel and cloned into a pGEMT-easy vector (Promega, Madison, USA). The plasmid that contained the PCR product was prepared for the preparation of more probes and sequenced to confirm. For screening of the $T$. yonseiensis genomic (DNA) library, the probe was labeled with $[\alpha-$ $\left.{ }^{32} \mathrm{P}\right] \mathrm{dCTP}$ using the Prime-a-Gene labeling system.

Screening of the T. yonseiensis genomic (DNA) library with isotope labeled probe. To locate $\lambda$ that contained the DNA polymerase gene, $\lambda$ plaques were lifted onto Hybond $\mathrm{N}+$ membranes (Amersham Pharmacia Biotech, Uppsala, Sweden), lysed, then hybridized with $\left[{ }^{32} \mathrm{P}\right]$-labeled probe. The plasmids were rescued according to the protocol of the ZAP Express ${ }^{\circledR}$ predigested Gigapack cloning kit (Stratagene, N. Torrey Pines Road, La Jolla, USA) into a pBK-CMV phagimids' vector using the Ex-Assist ${ }^{\circledR}$ helper phage. This plasmid was digested with ApaI and BamHI to remove the insert. It was analyzed on $1 \%$ agarose gel in a Trisacetate-EDTA (TAE) buffer.

Sequence analysis Sequences of the double-stranded plasmid DNA were determined using a Dye Terminator Cycle Sequencing
Ready mixture (Applied Biosystems, Foster City, USA) on a PCR system 2400 and ABI PRISM 310 Genetic Analyzer (Applied Biosystems, Foster City, USA). To sequence the DNA polymerase gene, the cloned plasmid was used as a source of the template DNA. Initial sequencing was performed using the T7 and SP6 primers as the primers. When necessary, additional primers were then synthesized as needed, using newly obtained sequence data. Sequence comparisons were done using the BLAST program (Altschul et al., 1990).

Inverse PCR for screening In order to isolate the part of the gene that encodes the DNA polymerase, inverse PCR was performed (Silver and Keerikatte, 1989). Three $\mu \mathrm{g}$ of the $T$. yonseiensis total DNA was cut with HindIII. This DNA was diluted $(1 / 10)$ and self-ligated to form circles. The proper-size DNA circles were isolated and amplified by PCR using two primers, designed according to the known DNA sequence from the first isolate. Sequences of the primers were as follows: sense primer (T3-3), 5'CCTTAAAGTGGATGTATTGTCCC-3'; antisense primer (T7-4), 5'-CTTTGTAAGAAAGTTTCACCAGG-3'. DNA amplification was performed using 2.5 units of $P f u$ DNA polymerase (Stratagene, N. Torrey Pines Road, La Jolla, USA) in a $50 \mu 1$ reaction mixture, which included $10 \times$ PCR reaction buffer, 20 pmol of each primer, $0.2 \mathrm{mM}$ of each dNTP, and $0.2 \mu \mathrm{g}$ of circular DNA. Prior to the reaction cycle, the mixture was heated to $96^{\circ} \mathrm{C}$ for $3 \mathrm{~min}$, followed by 30 cycles at $96^{\circ} \mathrm{C}$ for $30 \mathrm{sec}, 50 \sim 53^{\circ} \mathrm{C}$ for $30 \mathrm{sec}, 72^{\circ} \mathrm{C}$ for $4 \mathrm{~min}$, then the final extension at $72^{\circ} \mathrm{C}$ for $7 \mathrm{~min}$. After the final extension, 2.5 units of $T a q$ DNA polymerase was added to the reaction mixture and incubated at $72^{\circ} \mathrm{C}$ for $5 \mathrm{~min}$. The amplified $1.5 \mathrm{~kb}$ PCR product was identified on $1 \%$ agarose gel and subcloned into a pGEMT-easy vector (Promega, Madison, USA). This plasmid was sequenced by an automatic sequencer ABI310 (Applied Biosystems, Foster City, USA) in the same manner, as described previously.

Computer analysis The computer-assisted DNA and protein sequence analysis were performed using the DNASIS version 7.0 and PROSIS. The BLAST program at the NCBI server was used to search for sequence similarity.

Construction of the expression plasmid For the expression of the Tay DNA polymerase, four primers were designed. The first set, 5' end primer (Ex-k-6, 5' GGGAATTCCATATGGCAAAGTTTCT GTTAATTGATGGTAGCAG3') that contained the NdeI restriction enzyme site (under-lined) and 3' end primer (T7-4, 5' CTTTGTAA GAAAGTTTCACCAGG 3') was designed according to the sequence of the $1.5 \mathrm{~kb}$ inverse PCR product. The second set, 5' end primer (Ex-2-1, 5' GCATAGAATGTAAGAGTAAATATC 3') and 3' end primer (Ex-2, 5' CCGCTCGAGCTTAGCCAAAAACCAG TTAGG 3') that contained the XhoI restriction enzyme site at the end position (under-lined) was designed according to the sequence of $2.6 \mathrm{~kb}$ DNA that was identified first. The T7-4 and Ex-2 primers were in fact designed according to the $170 \mathrm{bp}$ DNA sequence that overlapped between the two isolates. DNA amplification was performed using two primers (Ex-k-6 and T7-4) on a $1.5 \mathrm{~kb}$ inverse PCR product as a template: 30 cycles at $96^{\circ} \mathrm{C}$ for $30 \mathrm{~s}, 58^{\circ} \mathrm{C}$ for $30 \mathrm{~s}, 72^{\circ} \mathrm{C}$ for $1 \mathrm{~min}$ and $30 \mathrm{~s}$, and $1.1 \mathrm{~kb}$ PCR product that was eluted from $1 \%$ agarose gel by the Gene-clean method (Bio101, 
Carlsbad, USA). Four cycles of the PCR reaction were performed using $1.1 \mathrm{~kb}$ DNA that was eluted from the gel and $2.6 \mathrm{~kb}$ firstisolated DNA as the mega-primer and template, respectively. Thirty amplifications were performed on the condition, denaturation $\left(96^{\circ} \mathrm{C}, 30 \mathrm{~s}\right)$, annealing $\left(58^{\circ} \mathrm{C}, 30 \mathrm{~s}\right)$, and extension $\left(72^{\circ} \mathrm{C}, 3 \mathrm{~min}\right)$. After the final cycle, two additional primers(Ex-k-6, Ex-2) that contained the NdeI and XhoI restriction enzyme site, respectively, were added to the reaction mixture. These continued for 30 cycles of amplification under the following conditions: denaturation $\left(96^{\circ} \mathrm{C}\right.$, $30 \mathrm{~s})$, annealing $\left(58^{\circ} \mathrm{C}, 30 \mathrm{~s}\right)$, and extension $\left(72^{\circ} \mathrm{C}, 5 \mathrm{~min}\right)$. The $2.6 \mathrm{~kb}$ amplified PCR product was identified on the $1 \%$ agarose gel. The PCR product was eluted and digested with NdeI and XhoI. The pET22b (+) expression vector (Novagen, Madison, USA), containing the sequence that encoded the C-terminal $6 \times$ His affinity tag, was digested with NdeI and $\mathrm{XhoI}$ in advance. The $2.6 \mathrm{~kb}$ PCR product and vector were ligated with T4 DNA ligase (Promega, Madison, USA) at $16^{\circ} \mathrm{C}$ overnight. The recombinant plasmid was introduced into E.coli $\mathrm{DH} 5 \alpha$ by the heat-shock method. The cloned $2.6 \mathrm{~kb}$ gene, coined tay, was identified by sequencing in the same manner, as described previously.

Expression and purification of the Tay DNA polymerase Protein, coined Tay, was expressed in E.coli BL21(DE3)pLysS. A single colony of $E$. coli BL21(DE3)pLysS that contained the recombinant DNA was picked. It inoculated $3 \mathrm{ml}$ of LB broth that contained $50 \mu \mathrm{g}$ of ampicillin per $\mathrm{ml}$. Then it was incubated at $37^{\circ} \mathrm{C}$ overnight. The overnight culture was transferred to $200 \mathrm{ml} \mathrm{LB}$ medium that contained $50 \mu \mathrm{g}$ of ampicillin per $\mathrm{ml}$. The culture was incubated until $\mathrm{OD}_{600}=0.5$, then induced with $1 \mathrm{mM}$ isopropyl- $\beta$ D-thiogalactopyranoside (IPTG), followed by further incubation for $3 \mathrm{~h}$. The cells were harvested by centrifugation $\left(5,000 \times g\right.$ at $4^{\circ} \mathrm{C}$ for $10 \mathrm{~min}$ ) and resuspended in $10 \mathrm{ml}$ binding buffer $(20 \mathrm{mM}$ Tris- $\mathrm{HCl}$ $\mathrm{pH} 7.9,0.5 \mathrm{M} \mathrm{NaCl}, 5 \mathrm{mM}$ imidazole). The cells were sonicated five times for $30 \mathrm{~s}$ each time with $30 \mathrm{~s}$ intervals. The cell debris was removed by centrifugation $\left(15,000 \times g\right.$ at $4^{\circ} \mathrm{C}$ for $\left.30 \mathrm{~min}\right)$. The supernatant was transferred to a $15 \mathrm{ml}$ conical tube and incubated in a $80^{\circ} \mathrm{C}$ water bath with shaking for $10 \mathrm{~min}$. The heat-treated supernatant was cooled on ice for $20 \mathrm{~min}$, then centrifuged $\left(17,000 \times g\right.$ at $4^{\circ} \mathrm{C}$ for $\left.30 \mathrm{~min}\right)$ to remove the denatured E. coli proteins. A His-bind resin and His-bind buffer kit (Novagen, Madison, USA) were used to purify the His-tagged protein, according to Novagens' manufacturers' instructions. The protein was eluted from resin with $3 \mathrm{ml}$ of the elution buffer (20 mM Tris$\mathrm{HCl} \mathrm{pH} 7.9,10 \mathrm{mM}$ imidazole, $0.5 \mathrm{M} \mathrm{NaCl}), 0.5 \mathrm{ml}$ per fraction. The protein concentration was measured according to Bradford (1976). The active fractions were pooled and dialyzed against the storage buffer $(20 \mathrm{mM}$ Tris- $\mathrm{HCl} \mathrm{pH} 7.9,100 \mathrm{mM} \mathrm{KCl}, 0.1 \mathrm{mM}$ EDTA, $1 \mathrm{mM}$ DTT) at $4^{\circ} \mathrm{C}$ overnight.

DNA polymerase assay The Tay DNA polymerase activity was measured by the modified assay method that was described previously (Bohlke et al., 2000). The method was based on the incorporation of $\left[\alpha-{ }^{32} \mathrm{P}\right] \mathrm{dCTP}$ in a DNA template (M13mp18 ssDNA). A $50 \mu \mathrm{l}$ reaction mixture that contained $5 \mu \mathrm{l} 10 \times \mathrm{Taq}$ reaction buffer $(100 \mathrm{mM}$ Tris- $\mathrm{HCl} \mathrm{pH} 8.3,500 \mathrm{mM} \mathrm{KCl}, 15 \mathrm{mM}$ $\mathrm{MgCl}_{2}$ ), $200 \mu \mathrm{M}$ each of dATP, dGTP, dTTP, dCTP, $1 \mu \mathrm{Ci}[\alpha-$ $\left.{ }^{32} \mathrm{P}\right] \mathrm{dCTP}$, enzyme solution $(1 \sim 10 \mu \mathrm{l})$, and $1 \mu \mathrm{g}$ of $\mathrm{M} 13 \mathrm{mp} 18$ ssDNA was annealed with $0.3 \mu \mathrm{g}$ of $(-20)$ forward primer. Assay reactions were incubated at $72^{\circ} \mathrm{C}$ for $30 \mathrm{~min}$, stopped on ice by the addition of $250 \mu \mathrm{l} 10 \% \mathrm{TCA}$, and kept on ice for $10 \mathrm{~min}$. The samples were filtered through GF/C filters (Whatman, Maidstone, UK). The filters were washed three times with $50 \mathrm{ml}$ of $5 \%$ TCA, $20 \mathrm{mM}$ sodium pyrophosphate, then washed with $70 \%$ ethanol. The washed filters were air-dried and counted by a liquid scintillation counter (Packard Bioscience, Billerica, USA). Taq DNA polymerase was used as a positive control. One unit is defined as the amount of enzyme that is necessary to incorporate $10 \mathrm{nmol}$ $\mathrm{dNTP}$ into an acid-insoluble form at $72^{\circ} \mathrm{C}$ in $30 \mathrm{~min}$.

Effect of pH, metal ion, dNTP concentration, and temperature on Tay DNA polymerase activity The recombinant Tay DNA polymerase was investigated for optimal reaction conditions using DNA polymerase assay, as described previously. The activity of Tay was measured in different conditions; $\mathrm{pH}, \mathrm{MgCl}_{2}$ concentration, and $\mathrm{KCl}$ concentration (Niehaus et al., 1997). The effect of the dNTP concentration on the activity of Tay was analyzed using 12\% polyacrylamide gel electrophoresis. The synthetic primer (Ex-kexo, 5' CCATCAATTAACAGAAACTTTGC 3') and the synthetic template (Ex-k, 5' GGGAATTCCATATGGCAAAGTTTCTGTTA ATTGATGG 3') were used in this assay. DNA polymerase activity of Tay was measured using 5'-[ $\left.{ }^{32} \mathrm{P}\right]$-labeled-primer and labeled primer/template hybrid. One pM to $10 \mu \mathrm{M}$ dNTPs and 0.02 unit of Tay were incubated in a $10 \times$ Tay buffer $(10 \mathrm{mM}$ Tris- $\mathrm{HCl} \mathrm{pH} 8.0$, $90 \mathrm{mM} \mathrm{KCl}, 2 \mathrm{mM} \mathrm{MgCl}_{2}$, reaction volume $25 \mu \mathrm{l}$ ) at $75^{\circ} \mathrm{C}$ for $30 \mathrm{~min}$. The reaction was stopped with $5 \mu \mathrm{l}$ formamide buffer on ice. The samples were analyzed by $12 \%$ polyacrylamide sequencing gel with $7 \mathrm{M}$ urea in a TBE buffer $(1500 \mathrm{~V}, 2 \mathrm{~h})$ and visualized by autoradiography.

Fidelity assay In order to investigate the fidelity of Tay DNA polymerase, gapped M13mp18 DNA was used as substrate (Campbell, 1995). Single- and double-stranded DNA were purified from a M13mp18 phage particle and E. coli, respectively (Sambrook et al, 1989). To obtain lacZ site gapped DNA, $2.7 \mu \mathrm{g}$ of the RF form of double-strand M13mp18 DNA was digested with HindIII and $B g$ III. A 650 bp DNA fragment that encoded the lac $Z$ region and 6.6 $\mathrm{kb}$ rest of the DNA were separated on $1 \%$ agarose gel. The $6.6 \mathrm{~kb}$ DNA that was eluted from the gel was denatured at $90^{\circ} \mathrm{C}$ for $5 \mathrm{~min}$, and the same molar ratio of single-strand M13mp18 DNA was added. The mixture was placed on ice for $5 \mathrm{~min}$, then SSC (300 mM $\mathrm{NaCl}, 30 \mathrm{mM}$ sodium citrate) was added to the final $2 \times$ concentration. The mixture was incubated at $60^{\circ} \mathrm{C}$ for $5 \mathrm{~min}$, then placed on ice. The hybridized DNA was precipitated with ethanol and resuspended in a TE buffer. The single-stranded DNA was converted to double-stranded circular DNA that contained 650 bp gap at the lac $Z$ site. DNA synthesis reaction was performed using a thermo cycler in a total volume of $25 \mu \mathrm{l}$. The reaction mixture contained 0.02 unit of Tay, $2.5 \mu \mathrm{l}$ of $10 \times$ Tay buffer, and $100 \mathrm{ng}$ of gapped DNA. The DNA synthesis reaction was incubated at $75^{\circ} \mathrm{C}$ for $10 \mathrm{~min}$ and stopped on ice by the addition of $4 \mathrm{mM}$ EDTA. Gap-filled DNA was introduced to the $E$. coli XL-1Blue MRF competent cell. The transformed cell was added to a tube at $48^{\circ} \mathrm{C}$, containing $3 \mathrm{ml}$ of soft agar, $500 \mu \mathrm{g}$ of IPTG, and $2.5 \mathrm{mg}$ of X-Gal. The soft agar that contained the transformed cell was poured onto the M9 minimal plate and solidified. The plate was incubated overnight at $37^{\circ} \mathrm{C}$, then scored for the mutant. 


\section{Results and Discussion}

Cloning and sequencing of the tay gene from $T$. yonseiensis The PCR reaction with the primers that were designed with the homologous region of DNA polymerases was successfully performed on the DNA $\lambda$ library that was prepared from the $T$. yonseiensis DNA. The PCR product was cloned in a pGEMTeasy vector and sequenced. The sequence of the PCR product was homologous with those of DNA polymerases from other bacteria (data not shown). Using this PCR product as a probe, the genomic DNA library of T. yonseiensis was screened. The positive spot was cloned to the $\mathrm{pBKCMV}$ phagimid vector and sequenced. A sequence analysis of the $2.6 \mathrm{~kb}$ DNA from the positive clone contained only a part of the 3 ' end of the gene encoding DNA polymerase. In order to find the rest of the gene, inverse PCR was performed. The $1.5 \mathrm{~kb}$ PCR product was obtained and sequenced. It contained the other parts of the DNA polymerase gene. The $1.5 \mathrm{~kb}$ DNA region from the 5 ' end of the $2.6 \mathrm{~kb}$ first isolate was homologous with those of DNA polymerase in other bacteria, whereas the $1.1 \mathrm{~kb}$ DNA region from the 3' end of the $1.5 \mathrm{~kb}$ inverse PCR product was homologous with them. Two segments of the
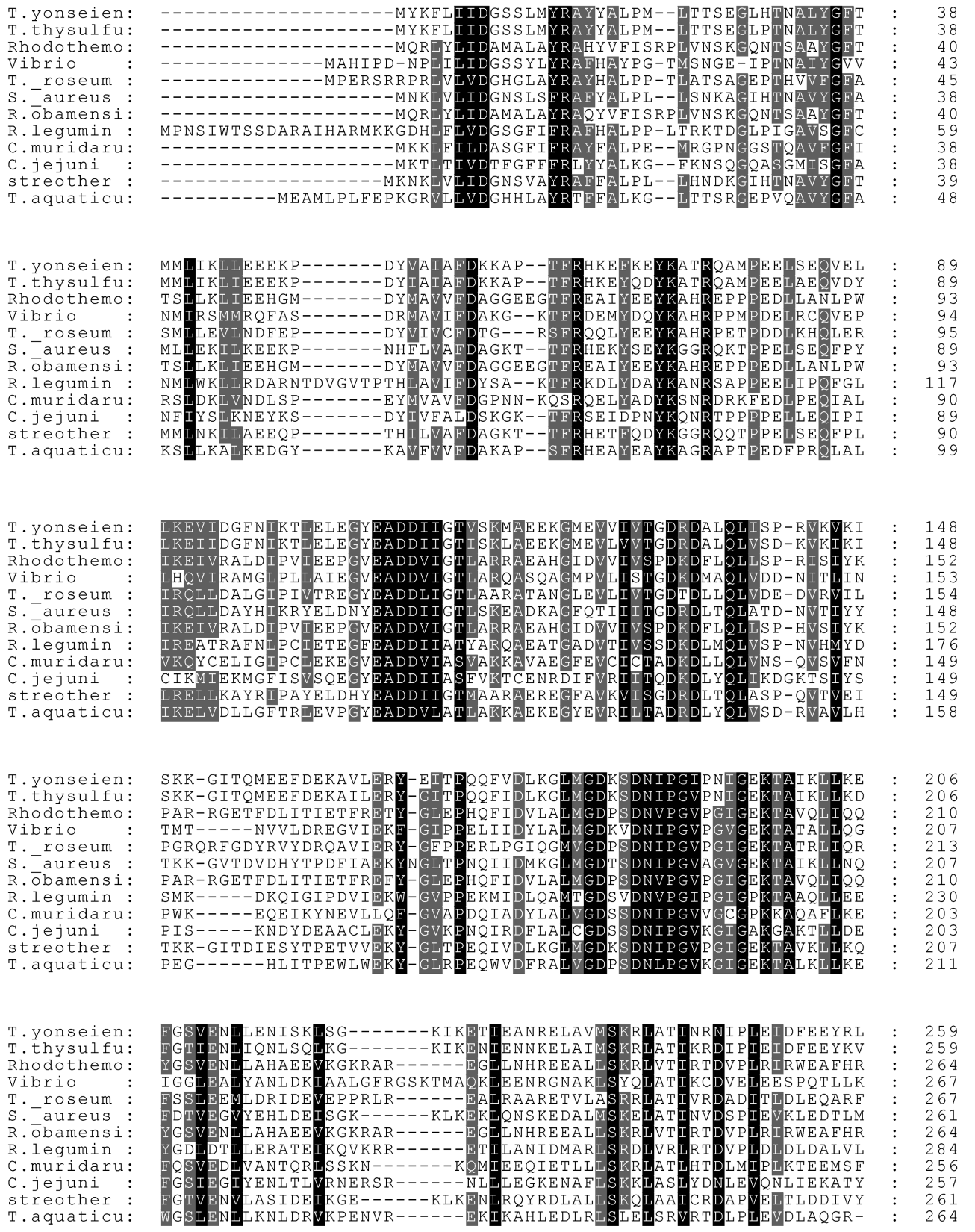

Fig. 1. Comparison of deduced amino acid sequence for Tay DNA polymerase from $T$. yonseiensis with those of other DNA polymerases. Tay DNA polymerase has a 39\%-47\% identity and 58\%-68\% similarity to amino acids sequence of other DNA polymerases. 

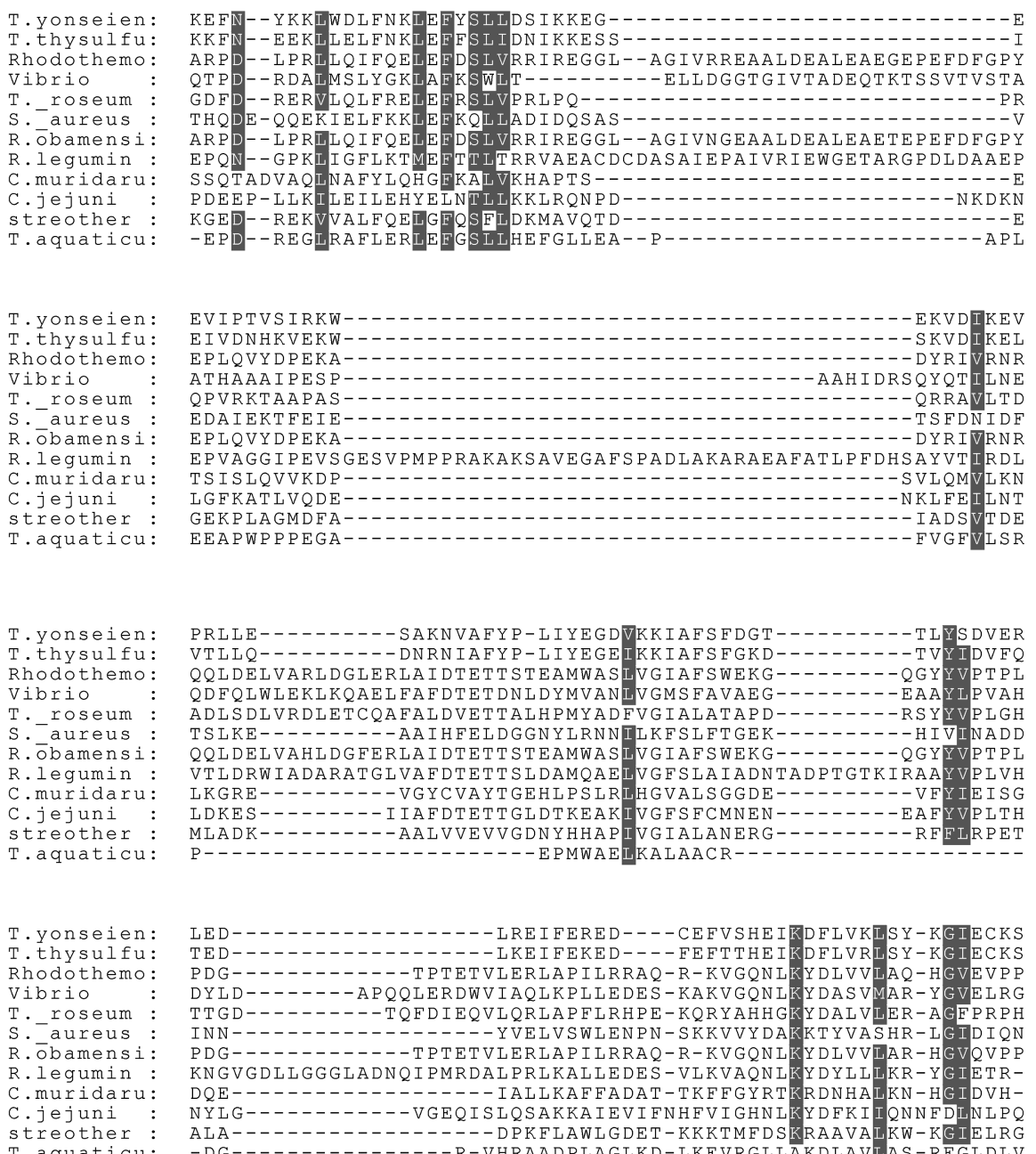

Fig. 1. Continued.

homologous DNAs were connected by PCR and sequenced. The connected gene, coined tay, has 2616 nucleotides and 872 deduced amino acids. The complete nucleotide sequence of tay was previously deposited at the GenBank database under the access number AY065997. The BLAST program analyzed the sequence of the tay gene. A deduced amino acid sequence of the tay gene has a 58-68\% homogeneity and $39-47 \%$ identity with those of DNA polymerase in other bacteria. The linear alignment of the amino acids from these genes is given in Fig. 1, showing the conserved domains.

Expression and purification The pET system (Novagen, Madison, USA) is one of the most powerful recombinant protein expression systems in $E$. coli. The pET22b(+) vector has a very strong $\mathrm{T} 7$ promoter and can be used in combination with pLysS to provide additional stringency (Dubenforff and Studier, 1991; Moffat and Pfaffle, 1995). The pLysS plasmids, which express the T7 lysozyme in the bacterial cytoplasm, strongly repress the protein expression from the $\mathrm{pET}$ vector in the absence of induction, thus enabling the expression of very toxic proteins. The tay gene was amplified using Pfu DNA polymerase and cloned into the NdeI site of pET22b (+), according to previously mentioned methods. The cloned tay gene was transformed into E. coli BL21(DE3)pLysS at $37^{\circ} \mathrm{C}$. The selected colony was grown in a LB medium that was supplemented with ampicillin. Overexpression was induced 

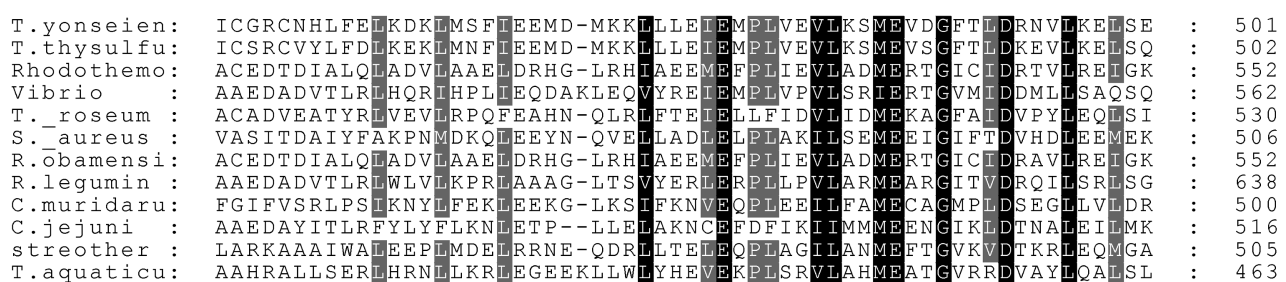

T.yonseien: . thysulfu: Vibrio

T._roseum :

S. aureus:

R.legumin

C.muridaru:

C.jejuni

streother
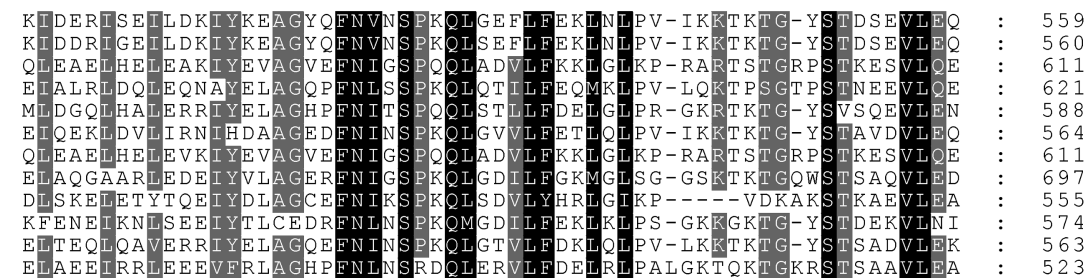

T.yonseien: T. thysulfu: Rhodothemo: Vibrio

T. roseum

S.- aureus

R.obamensi:

R.legumin :

C.muridaru:

C.jejuni

streother:
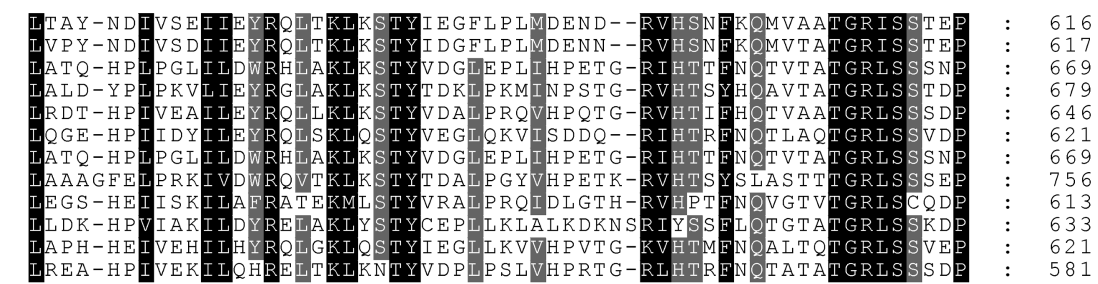

T.yonseien: T. thysulfu: Rhodothemo: Vibrio

T._roseum

S. aureus

R.ōbamensi:

R. legumin

C.muridaru:

c.jejuni

streother
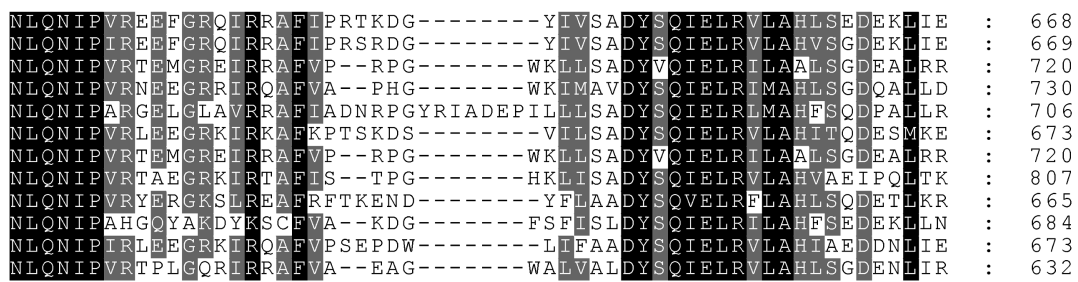

T.yonseien: T.thysulfu: Vibrio

T. roseum

T._roseum

R.obamensi:

R.legumin:

C.muridaru:

C.jejuni

streother

T.aquaticu:
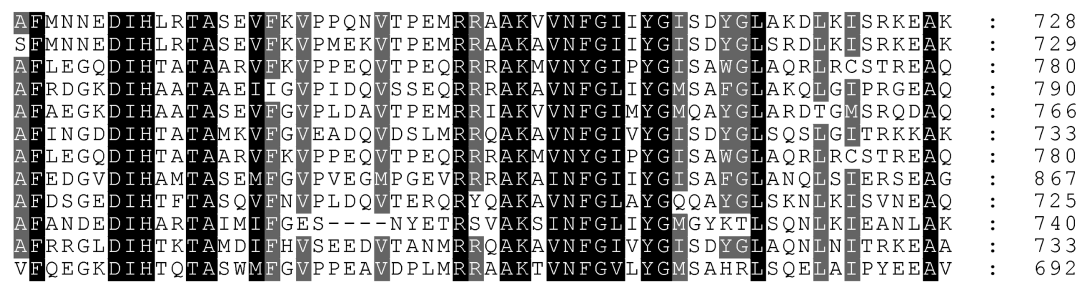

Fig. 1. Continued.

by the addition of IPTG (final concentration $1 \mathrm{mM}$ ). After a 3 $\mathrm{h}$ induction by IPTG, the cell was harvested and sonicated. Most of the E. coli proteins were denatured and precipitated by heat treatment at $80^{\circ} \mathrm{C}$ for $10 \mathrm{~min}$, but some of the $E$. coli proteins remained soluble after heating (Niehaus et al, 1997). The soluble supernatant (after the heating step) was then purified with a Ni-NTA affinity column. Table 1 gives an overview of the purification procedure. The eluted protein was run in $10 \%$ SDS-PAGE (Fig. 2). The apparent molecular mass of protein was a $97 \mathrm{kDa}$, which correlated well to the predicted size from the nucleotide sequence data. The DNA polymerase activity of the purified protein, Tay, was measured using the modified acid precipitation method. One unit of Tay was defined as the amount of protein that catalyzed the incorporation of $10 \mathrm{nmol}$ dNTP into an acid-insoluble form at $75^{\circ} \mathrm{C}$ for $30 \mathrm{~min}$. After dialysis of Tay against the storage buffer, the DNA polymerase activity was 536 unit/mg for the purified His-tagged Tay DNA polymerase that was isolated from $200 \mathrm{ml} E$. coli culture.

Effect of pH, metal ion, dNTP concentration, and temperature on the activity of the Tay DNA polymerase. Characteristics of the Tay DNA polymerase (such as optimum $\mathrm{pH}$, temperature, and required concentration of metal ion and dNTP) were determined. The effects of $\mathrm{pH}$ on the activity of Tay with three different buffers were used. Tay showed 

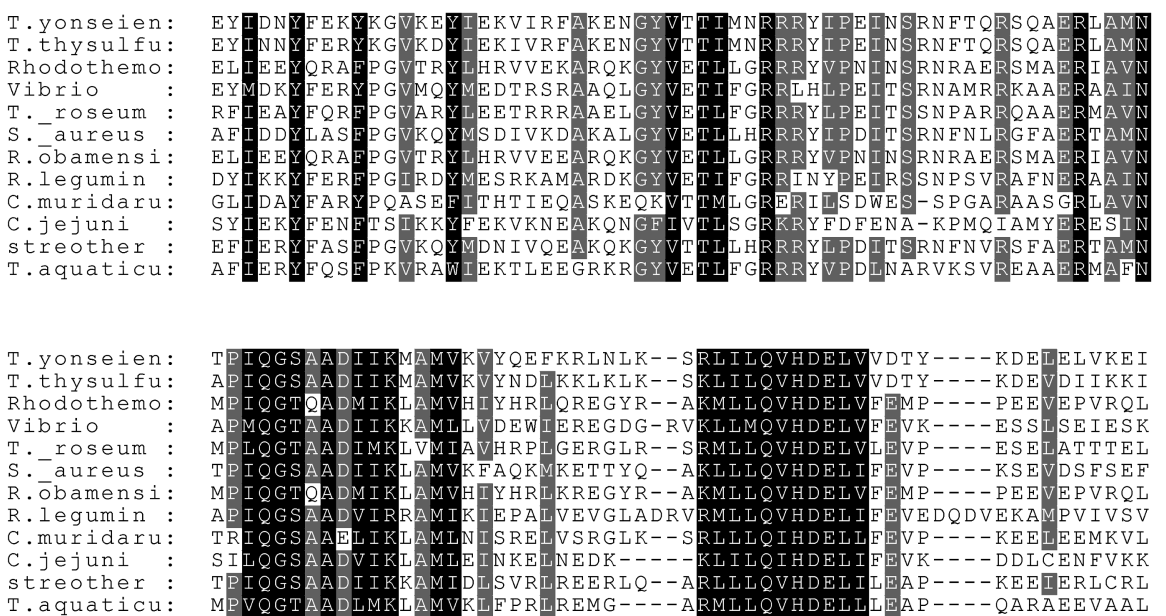

T.yonseien: T. thysulfu: Rhodothemo: Vibrio

T. roseum

S._aureus

R.ōbamensi:

R.legumin :

C.muridaru:

c.jejuni

streother
T.aquaticu:
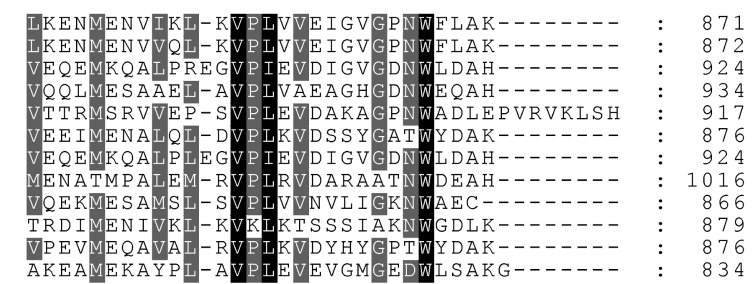

Fig. 1. Continued.

Table 1. Purification of recombinant Tay DNA polymerase

\begin{tabular}{ccccc}
\hline Purification step & $\begin{array}{c}\text { Total protein } \\
(\mathrm{mg})\end{array}$ & $\begin{array}{c}\text { Total activity } \\
\text { (units) }\end{array}$ & $\begin{array}{c}\text { Specific activity } \\
\text { (units/mg) }\end{array}$ & $\begin{array}{c}\text { Yield } \\
(\%)\end{array}$ \\
\hline Crude extract & 38.64 & 1371.33 & 35.49 & 100 \\
Heat-treatment & 9.99 & 744.05 & 74.48 & 54.26 \\
His-resin & 0.45 & 241.37 & 536.38 & 17.60 \\
\hline
\end{tabular}

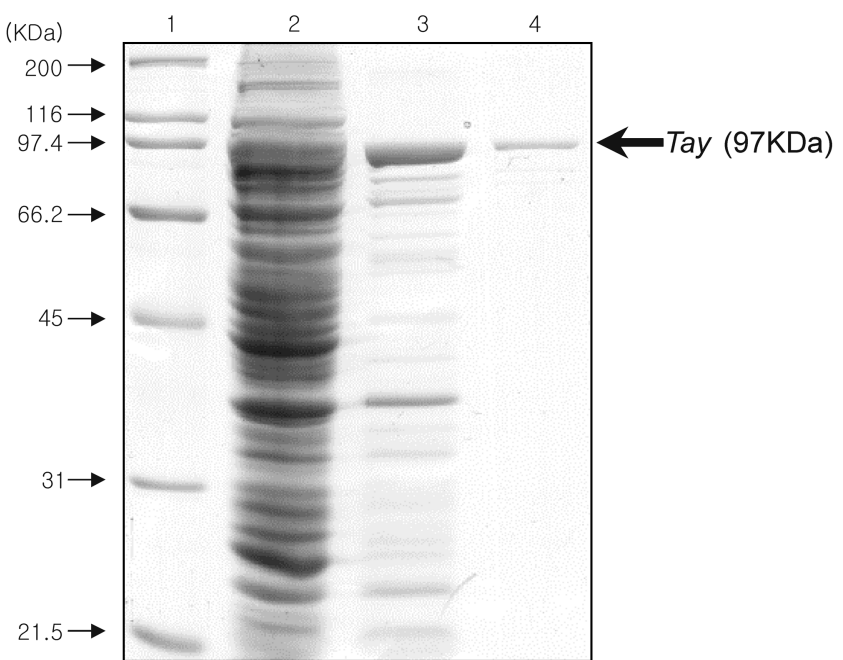

Fig. 2. SDS-PAGE analysis of Tay DNA polymerase. Lane 1, Size Marker; Lane 2, Lysate from E.coli BL21(DE3)pLysS carrying the vector with tay gene; Lane 3 , Heat $\left(80^{\circ} \mathrm{C}, 10 \mathrm{~min}\right)$ treated lysate from E.coli BL21(DE3)pLysS carrying the vector with tay gene; Lane 4, Tay purified from His-Bind resin. maximum activity at the Tris-HCl buffer, $\mathrm{pH} 8.0$ (Fig. 3A). Like all of the other DNA polymerase, Tay required divalent cation as a cofactor. Optimal activity was obtained with 2.5 $\mathrm{mM} \mathrm{MgCl}$ (Fig. 3B). The optimal concentration of $\mathrm{KCl}$ is 90 $\mathrm{mM}$ (Fig. 3C). The effect of temperature on the catalytic activity of the Tay was shown (Fig. 3D) to be optimum between $70 \sim 80^{\circ} \mathrm{C}$. The polymerase activity of Tay was shown at a dNTP concentration over $100 \mathrm{nM}$ (Fig. 4). In order to identify the $3 \rightarrow 5$ ' exonuclease activity (proofreading activity) of Tay DNA polymerase, a $12 \%$ polyacrylamide sequencing gel was used. A $5^{\prime}-\left[{ }^{32} \mathrm{P}\right]$ labeled-primer and primer/template synthetic oligonucleotide were used as a substrate in this assay. Under these artificial conditions, both the single- and double-stranded DNA were not degraded (Fig. 4). This indicates that the Tay DNA polymerase has no 3' $\rightarrow 5$ ' exonuclease activity.

Fidelity for Tay DNA polymerase Polymerization errors are rare events relative to correct incorporations. Highly sensitive assays are required to measure DNA polymerase fidelity. In order to detect the fidelity of Tay DNA polymerase, 

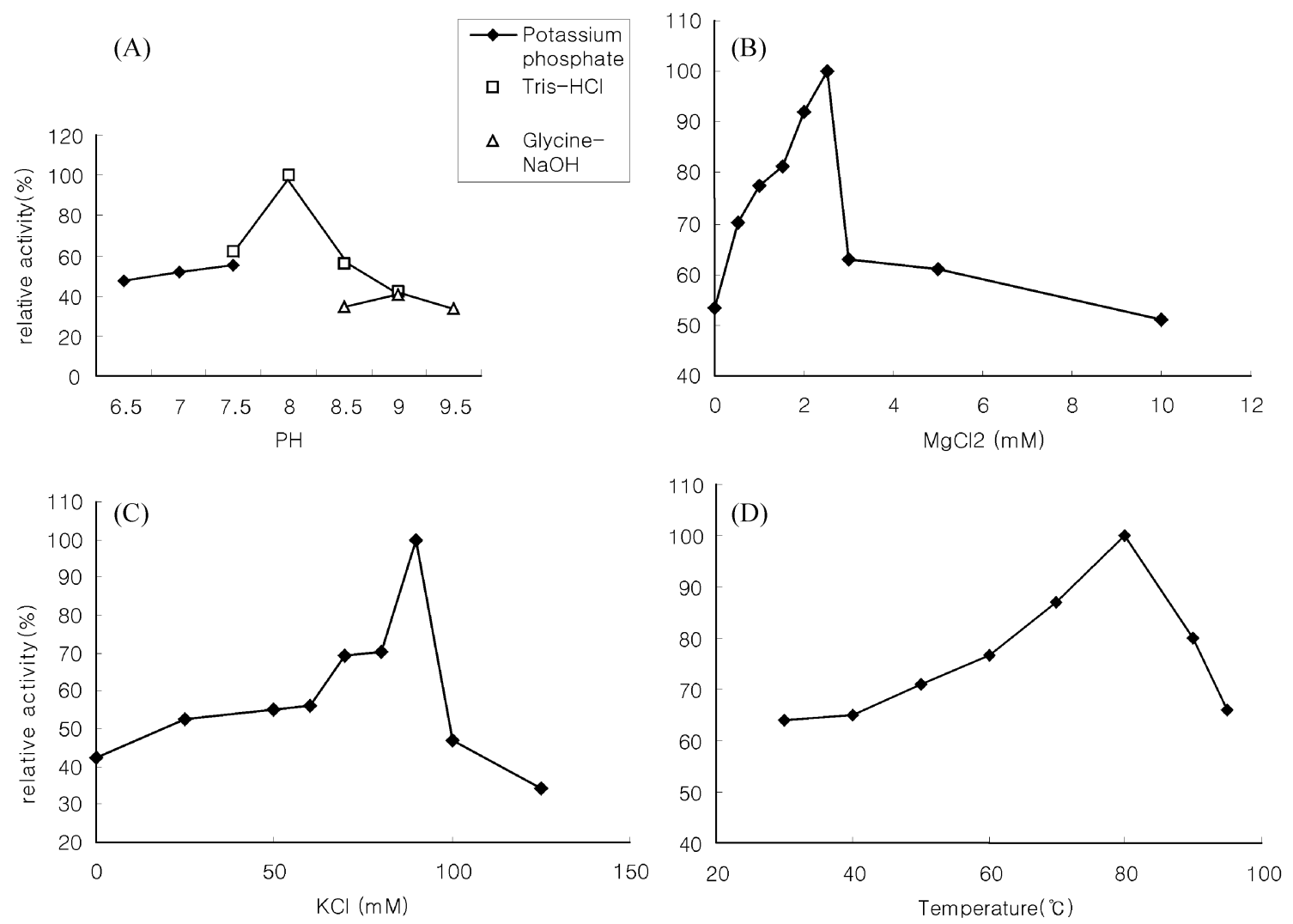

Fig. 3. Effects of $\mathrm{pH}(\mathrm{A}), \mathrm{MgCl}_{2}(\mathrm{~B}), \mathrm{KCl}(\mathrm{C})$, and temperature (D) on Tay activity

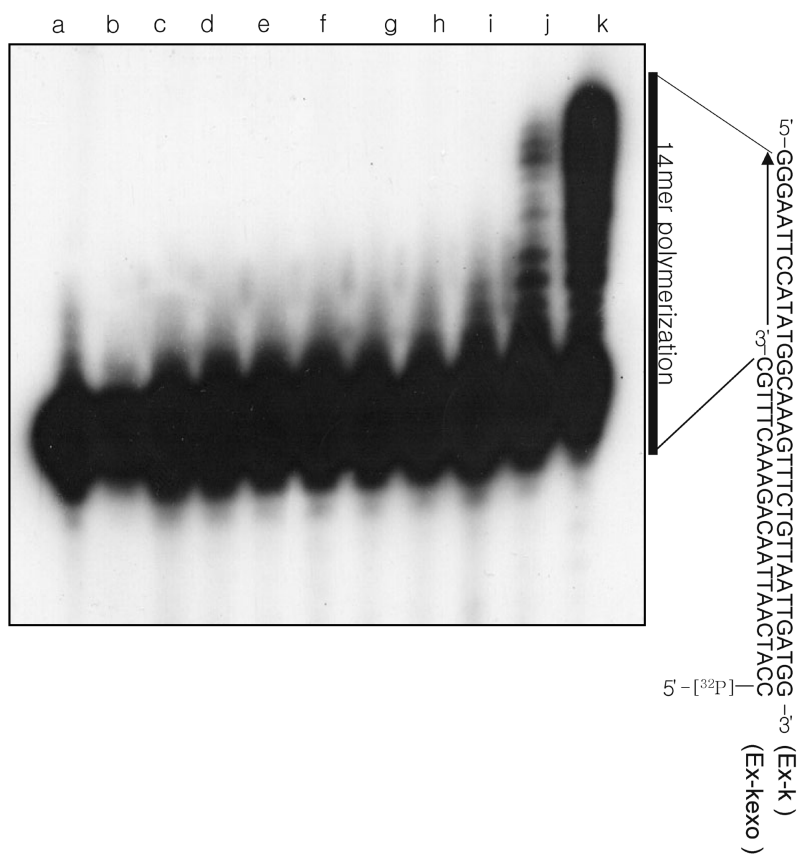

Fig. 4. The nucleotide incorporation dependence on dNTP concentration. Lane (a), primer only; Lane (b), primer assay without dNTP; Lane(c)-(k), assay with primer-template and increasing concentration of dNTP; (c) $0 \mathrm{M}$, (d) $1 \mathrm{pM}$, (e) $10 \mathrm{pM}$, (f) $100 \mathrm{pM}$, (g) $1 \mathrm{nM}$, (H) $10 \mathrm{nM}$, (I) $100 \mathrm{nM}$, (j) $1 \mu \mathrm{M}$, (k) $10 \mu \mathrm{M}$. an assay was performed by monitoring polymerase errors that inactivate the nonessential $\alpha$-complementation activity of the lacZ gene in bacteriophage M13mp18. A gapped M13mp18 substrate was constructed in the single-strand gap that contains the lac $Z \alpha$-complementation target sequence. DNA polymerase was used for the gap-filling synthesis in this assay. If synthesis to fill in the gap in a wild-type DNA substrate is error free, then the $\alpha$-peptide that is produced from this DNA complements the defective $\beta$-galactosidase activity of the host cell to hydrolyze the X-Gal. This results in dark blue M13 plaques. Errors that are introduced during the gap-filling synthesis result in blue or colorless plaques. The fidelity of Tay and other reference enzymes are presented in Table 2. The mutation frequency of Tay was compared to those of Taq and Pfu DNA polymerase. Tay has higher polymerization fidelity than that of Taq DNA polymerase, and lower polymerization fidelity than that of $P f u$ DNA polymerase.

Table 2. Fidelity measurement of three DNA polymerases

\begin{tabular}{cccc}
\hline \multirow{2}{*}{ Enzymes } & \multicolumn{2}{c}{ Plaques } & $\begin{array}{c}\text { Mutant } \\
\text { frequency }\end{array}$ \\
\cline { 2 - 3 } & Total & Mutant & \\
\hline Taq & 718 & 6 & $8 \times 10^{-3}$ \\
Tay & 964 & 4 & $4 \times 10^{-3}$ \\
Pfu & 963 & 1 & $1 \times 10^{-3}$ \\
\hline
\end{tabular}


In summary, Tay DNA polymerase of $T$. yonseiensis was expressed in E. coli and purified. Tay has a molecular weight of approximately $97 \mathrm{kDa}$ on SDS-PAGE when measured on SDS-PAGE. It does not possess $3^{\prime} \rightarrow$ ' ' exonuclease activity. The optimum temperature of DNA synthesis is approximately $70-80^{\circ} \mathrm{C}$ under assay conditions. The optimal magnesium and potassium ion concentrations for DNA synthesis are $2.5 \mathrm{mM}$ and $90 \mathrm{mM}$, respectively. Tay exhibited a half-life of approximately $10 \mathrm{~min}$ at $90^{\circ} \mathrm{C}$ under optimal conditions. This suggests that Tay is also a thermostable enzyme. However, the thermostability of Tay is not enough for PCR. The PCR and strand displacement amplification (SDA) are two methods of amplifying the nucleic acid sequence. SDA differ from PCR since it is an isothermal amplification process (i.e. all reactions occur at the same temperature without the need for an elevated temperature to melt DNA strands). Primarily, the exonuclease-deficient DNA polymerases have been used in SDA (Walker et al, 1992). Therefore, exonuclease activity deficient Tay DNA polymerase will be suitably used in SDA with a thermostable restriction enzyme (e.g. BsoBI). The Tay DNA polymerase will also be used for determining the sequence of single-stranded DNA templates that form stable secondary structures at $37^{\circ} \mathrm{C}$. The formation of a secondary structure in the ssDNA template will be prevented, because Tay DNA polymerase works efficiently at $70-80^{\circ} \mathrm{C}$.

Acknowledgments This work was supported by a grant from the Korea Science and Engineering Foundation through the Bioproducts Research Center at the Yonsei University.

\section{References}

Altschul, S. F., Gish, W., Miller, W., Myers, E. W. and Lipman, D. J. (1990) Basic local alignment search tool. J. Mol. Biol. 215, 403-410.

Bohlke, K., Pisoni, F. M., Volgias, C. E., Frey, B., Sobek, H. and Antranikian, G. (2000) PCR performance of the B-type DNA polymerase from the thermiphilic euryarchaeon Thermococcus aggregans improved by mutations in the Y-GG/A motif. Nucleic Acids Res. 28, 3910-3917.

Bradford, M. M. (1976) A rapid and sensitive method for the quantitation of microgram quantities of protein utilizing the principle of protein-dye binding. Anal. Biochem. 72, 248-254.

Campbell, J. L. (1995) DNA replication. Methods in Enzymol. 262, 217-233.

Cariello, N. F., Swenberg, J. A. and Skopek, T. R. (1991) Fidelity of Thermococcus litoralis DNA polymerase (Vent) in PCR determined by denaturating gradient gel electrophoresis. Nucleic Acids Res. 19, 4193-4198.

Chien, A., Edgar, D. B. and Trela, J. M. (1976) Deoxyribonucleic acid polymerase from the extreme thermophile Thermus aquaticus. J. Bacteriol. 127, 1550-1557.

Cline, J., Braman, J. and Hogrefe, H. H. (1996) PCR fidelity of $P f u$ DNA polymerase and other thermostable DNA polymerase. Nucleic Acids Res. 24, 3546-3551.

Dabrowski, S. and Kur, J. (1998) Cloning and expression in Escherichia coli of the recombinant His-tagged DNA polymerase from Pyrococcus furiosus and Pyroccus woesei. Protein Expression Purif. 14, 131-138.

Dubendorff, J. W. and Studier, F. W. (1991) Controlling basal expression in an inducible $\mathrm{T} 7$ expression system by blocking the target T7 promoter with lac repressor. J. Mol. Biol. 219, 45-59.

Efstratiadis, A., Kafatos, F. C., Maxam. A. M. and Maniatis, T. (1976) Enzymatic in vitro synthesis of globin genes. Cell 7, 279.

Frey, B. and Suppmann, B. (1995) Demonstration of the Expend PCR Systems greater fidelity and higher yields with a lacIbased fidelity assay. Biochemica 2, 34-35.

Jang, H. J., Kim, B. C., Pyun, Y. R. and Kim, Y. S. (2002) A novel subtilisin-like serine protease from Thermoanaerobacter yonseiensis KB-1: cloning, expression and biochemical properties. Extremophiles, in press.

Jung, S. E., Choi, J. J., Kim, H. K. and Kwon, S. T. (1997) Cloning and analysis of DNA polymerase-encoding gene from Thermus filiformis. Molecules and Cells 7, 769-776.

Kaledin, A. S., Sliusarenko, A. G. and Gorodetskii, S. I. (1981) Isolation and properties of DNA polymerase from the extreme thermophilic bacterium Thermus Flavus. Biokhimiia 46, 15761584.

Kim, B. C., Grote, R., Lee, D. W., Antranikian, G. and Pyun, Y. R. (2001) Thermoanaerobacter yonseiensis sp. nov., a novel extreme thermophilic, xylose-utilizing bacterium that grows at up to $85^{\circ}$ C. Int. J. Syst. Evol. Microbiol. 51, 1539-1548.

Kim, J. S., Koh, S., Kim, J. J., Kwon, S. T. and Lee, D. S. (1998) Top Dna polymerase from Thermus thermophilus HB 27: Gene cloning, sequence determination, and physicochemical properties. Molecules and Cells 8, 157-161.

Kim, S. S. and Yu, Y. G. (2001) Molecular cloning of an extremely thermostable alanine racemase from Aquifex pyrophilus and enzymatic characterization of the expressed protein. J. Biochem. Mol. Biol. 33, 82-88.

Kim, Y., Hong, Y. B., Suh, S. W. and Jung, G. (2000) Nucleotide insertion fidelity of human Hepatitis B viral polymerase. $J$. Biochem. Mol. Biol. 33, 126-132.

Kong, H., Kucera, R. B. and Jack, W. E. (1993) Characterization of a DNA polymerase from the hyperthermophile archaea Thermococcus litoralis. J. Biol. Chem. 268, 1965-1975.

Kornberg, A. (1980) DNA Replication, pp. 1-4 and 101-166, W. H. Freeman and Company, San Francisco.

Lu, C. and Erickson, H. P. (1997) Expression in Escherichia coli of the thermostable DNA polymerase from Pyrococcus furiosus. Protein Expression Purif. 11, 179-184.

Lunberg, K. S., Shoemaker, D. D., Adams, M. W. W., Short, J. M., Sorge, J. A. and McArthur, E. J. (1991) High-fidelity amplification using a thermostable polymerase isolated from Pyrococcus furiosus. Gene 108, 1-6.

Moffatt, B. A. and Pfaffle, P. K. (1995) Single-step purification of a thermostable DNA polymerase expressed in Escherichia coli. BioTechniques 19, 780-784.

Mullis, K., Faloona, F., Saiki, R., Horn, G. and Ehrlich, H. (1986) Specific enzymatic amplification of DNA in vitro: the polymerase chain reaction. Cold Spring Harbor Symp. Quant. Biol. 247, 7116-7122.

Niehaus, F., Frey, Bruno. and Antranikian. (1997) Cloning and characterization of a thermostable $\alpha$-DNA polymerase from the hyperthermophilic archaen Thermococcus sp.TY. Gene 204, 
153-158.

Perler, F. B., Kumar, S. and Kong, H. (1996) Thermostable DNA polymerase. Adv. Protein Chem. 48, 377-435.

Ruttimann, C., Cotoras, M., Zaldivar, J. and Vicuna, R. (1985) DNA polymerase from the extremely thermophilic bacterium Thermus thermophilus HB. Eur. J. Biochem. 149, 41-46.

Saiki, R. K., Gelfand, D. H., Stoffel, S., Scharf, S. J., Higuchi, R., Horn, G. T., Mullis, K. B. and Erlich, H. A. (1988) Primerdirected enzymatic amplification of DNA with a thermostable DNA polymerase. Science 239, 487-491.

Sambrook, J., Frisch, E. F. and Maniatis, T. (1989) Molecular Cloning: A laboratory Manual, 2nd ed., Cold Spring Harbor
Laboratory Press, New York.

Silver, J. and Keerikatte, V. (1989) Novel use of polymerase chain reaction to amplify cellular DNA adjacent to an integrated provirus. J. Virol. 63, 1924-1928.

Tabor, S. and Richardson, C. C. (1987) DNA sequence analysis with a modified bacteriphage T7 DNA polymerase. Proc. Natl. Acad. Sci. USA 84, 4767.

Walker, G. T., Little, M. C., Nadeau, J. G. and Shank, D. D. (1992) Isothermal in vitro amplification of DNA by a restriction enzyme/ DNA polymerase system. Proc. Natl. Acad. Sci. USA 89, 392-396. 